\title{
The use of marine-derived fungi for preparation of enantiomerically pure alcohols
}

\author{
Hui Liu ${ }^{1,2} \cdot$ Fayene Zeferino Ribeiro de Souza ${ }^{3} \cdot{\text { Lan } \text { Liu }^{1,2,4} \cdot \text { Bi-Shuang Chen }}^{1,4}$ (i) \\ Received: 11 October 2017 /Revised: 27 November 2017 / Accepted: 11 December 2017 / Published online: 20 December 2017 \\ (C) Springer-Verlag GmbH Germany, part of Springer Nature 2017
}

\begin{abstract}
A highly enantioselective and minimally polluting approach to optically pure chiral alcohols is developed using cheap, readily available and sustainable marine-derived fungi as catalysts. An evaluation of the synthetic potential of 13 Chinese marine fungi was performed to screen for enantioselective reduction of 13 aromatic ketones from different compound classes as substrates. Good yields and excellent enantioselectivities were achieved with this method. In details, first the effects of several crucial variables on the bioreduction of aromatic ketones with whole cells of marine fungi were explored systematically. Next, we obtained insight into the substrate scope of the tested fungi under the optimized conditions, and selected reduction processes were performed at a commercial scale of up to $1000 \mathrm{~mL}$ to determine scalability, which led to excellent yields and enantioselectivities. Last, ketone reductases from two prioritized fungi exhibited good recyclability, with those of Rhodotorula mucilageinosa giving $a>95 \%$ yield with up to $99 \%$ ee during 3 cycles and those of Rhodotorula rubra giving $a>95 \%$ yield with up to $99 \%$ ee during 9 cycles.
\end{abstract}

Keywords Chiral alcohols $\cdot$ Marine fungi $\cdot$ Enantioselective reduction $\cdot$ Scalability $\cdot$ Recyclability

\section{Introduction}

The term "Biocatalysis" designates an enabling technology for chemists, which has been applied in many chemical transformations aiming for more environmentally friendly processes (Schmid 2001; Straathof 2013; Torrelo et al. 2015). Therefore, biocatalysis is currently established as a useful tool and integral part of chemical activities, including the production of renewable raw materials and clean energy and the biodegradation of

Electronic supplementary material The online version of this article (https://doi.org/10.1007/s00253-017-8707-5) contains supplementary material, which is available to authorized users.

Bi-Shuang Chen

chenbsh23@mail.sysu.edu.cn

1 School of Marine Sciences, Sun Yat-Sen University, Guangzhou 510275, People's Republic of China

2 South China Sea Bio-Resource Exploitation and Utilization Collaborative Innovation Center, Sun Yat-Sen University, Guangzhou, China

3 Departamento de Química, Faculdade de Ciências, UNESP, Bauru 17033-360, Brazil

4 Guangdong Provincial Key Laboratory of Marine Resources and Coastal Engineering, Guangzhou 510275, China environmental contaminants (Gavrilescua and Chisti 2005). The rapidly expanding scope of biocatalysis makes it a viable alternative to conventional chemical methods (Patel 2008). Hans-Peter and Werbitzky (2011) have estimated that by 2020, $20 \%$ of global production of all synthetic chemicals will be achieved through biocatalysis.

The development of biocatalysis requires novel biocatalysts in the form of isolated enzymes or whole cells (Liu et al. 2004), leading to a growing demand for robust and efficient biocatalysts. Fungi from marine environments are thoroughly adapted to surviving and growing under harsh conditions (Burton et al. 2002). Such habitat-related characteristics are desirable features from a general biotechnological perspective and are of key importance to exploit a microorganism's enzymatic potential (Trincone 2011, 2010). Indeed, marine microorganisms host novel enzymes showing optimal activities at extreme values of salt concentrations, $\mathrm{pH}$, and temperature, compared to enzymes isolated from terrestrial origins (Antranikian et al. 2005; Dionisi et al. 2012; Ferrer et al. 2012). These advantages, in addition to their chemical and stereochemical properties and readily available sources (e.g., sea sources of enzymes represented by microorganisms or fungi, plants or animals; ease of growth), make marine 
enzymes ideal biocatalysts for fine chemistry and pharmaceutical sectors; these enzymes should be broadly explored (Trincone 2011; Rocha et al. 2010, 2012, 2015; de Oliveira et al. 2014; De Vitis et al. 2015; Sarkar et al. 2010).

Optically pure chiral alcohols are an important class of compounds often found as a common structural motif in chiral pharmaceuticals, flavors, agrochemicals, and functional materials (Hertweck 2009; Chen et al. 2011). There has been growing interest in chiral alcohols in organic synthesis, due to the increasing importance of bioactive molecules containing these functionalities (Pàmies and Bäckvall 2001; Brenelli and Fernandes 2003). In this context, novel methods concerning the preparation of chiral alcohols with high yield and enantioselectivity are of considerable interest.

Continuing our longstanding interest in the application of marine fungi (Chen and Hanefeld 2013; Chen et al. 2015), and in conjunction with our recent interest in the synthesis of optically pure chiral alcohols (Chen et al. 2011, 2017; Chen and Hanefeld 2013), in the present study, we became interested in the enantioselective reduction of prochiral aromatic ketones using marine-derived fungi, offering an alternative, highly enantioselective and minimally polluting route to important chiral alcohols. Here, we report the results of the evaluation of 13 fungi isolated from marine sources as promising biocatalysts for the enantioselective reduction of a variety of carbonyl compounds from various compound classes.

\section{Materials and methods}

\section{General methods}

All chemicals were purchased from Sigma-Aldrich (Schnelldorf, Germany) and used without further purification unless otherwise specified. The culture media components were obtained from BD (Becton, Dickinson and Company, Germany).

${ }^{1} \mathrm{H}$ and ${ }^{13} \mathrm{C}$ NMR spectra were recorded with a Bruker Advance 400 instrument (400 and $100 \mathrm{MHz}$, respectively) and internally referenced to residual solvent signals. Data for ${ }^{1} \mathrm{H}$ NMR are reported as chemical shift (d ppm), multiplicity ( $\mathrm{s}=$ singlet, $\mathrm{d}=$ doublet, $\mathrm{t}=$ triplet, $\mathrm{q}=$ quartet, $\mathrm{m}=$ multiplet $)$, integration, coupling constant $(\mathrm{Hz})$, and assignment. Data for ${ }^{13} \mathrm{C}$ NMR are reported in terms of chemical shift. Optical rotations were obtained at $20^{\circ} \mathrm{C}$ with a PerkinElmer 241 polarimeter (sodium D line). Column chromatography was performed with silica gel $(0.060-0.200 \mathrm{~mm}$, pore diameter ca. $6 \mathrm{~nm}$ ) and mixtures of petroleum ether (PE) and ethyl acetate (EtOAc) as solvents. Thin-layer chromatography (TLC) was performed on $0.20 \mathrm{~mm}$ silica gel $60-\mathrm{F}$ plates. Organic solutions were concentrated under reduced pressure with a rotary evaporator.
Reaction products were analyzed by chiral HPLC analysis using a Shimadzu LC-10AT VP series and a Shimadzu SPDM10Avp photo diode array detector $(190-370 \mathrm{~nm})$ with a Chiralcel AD-H column (eluent: $n$-hexane $/ i$-PrOH $(95: 5, v / v)$; flow rate, $0.5 \mathrm{~mL} / \mathrm{min}$; column temperature $25^{\circ} \mathrm{C}$ ). The yields (quantified using calibration curves) and product $e e$ values of analytes were determined by chiral HPLC analyses according to the following retention time data: propiophenone (1a) [1a, $10.94 \mathrm{~min}$; $(R)-\mathbf{2 a}, 14.74 \mathrm{~min} ;(S)-\mathbf{2 a}, 16.49 \mathrm{~min}]$, acetophenone (1b) [1b, $11.46 \mathrm{~min} ;(R)-\mathbf{2 b}, 15.93 \mathrm{~min}$; $(S)-\mathbf{2 b}$, $17.93 \mathrm{~min}$ ], 2-bromo-1-phenylethanone (1c) [1c, $16.42 \mathrm{~min}$; $(R)-\mathbf{2 c}, 22.33 \mathrm{~min}$; $(S)-\mathbf{2 c}, 27.39 \mathrm{~min}], 2$-chloro-1phenylethanone (1d) [1d, 16.75; $(R)-2 d, 20.98 \mathrm{~min} ;(S)-\mathbf{2 d}$, $24.71 \mathrm{~min}$ ], 1-(4-bromophenyl)ethanone $(\mathbf{1 g})$ [1g, $11.21 \mathrm{~min}$; $(S)-\mathbf{2 g}, 16.83 \mathrm{~min} ;(R)-\mathbf{2 g}, 17.99 \mathrm{~min}], 1-(4-$ chlorophenyl)ethanone $(\mathbf{1 h})[\mathbf{1 h}, 10.78 \mathrm{~min} ;(R)-\mathbf{2 h}$, $15.09 \mathrm{~min} ;(S)-2 \mathrm{~h}, 16.09 \mathrm{~min}$ ], 1-(3-chlorophenyl)ethanone (1i) [1i, $10.49 \mathrm{~min} ;(R)-2 \mathbf{i}, 14.60 \mathrm{~min} ;(S)-2 \mathbf{i}, 16.35 \mathrm{~min}]$, 1-(2-chlorophenyl)ethanone $(\mathbf{1 j})[\mathbf{1 j}, 10.71 \mathrm{~min} ;(R)-\mathbf{2} \mathbf{j}$, $13.32 \mathrm{~min} ;(S)-\mathbf{2} \mathbf{j}, 13.98 \mathrm{~min}]$, and 1-bromo-1-(4bromophenyl)ethanone (11) [11, $17.57 \mathrm{~min}$; (S)-2l, $21.65 \mathrm{~min}$; and $(R)-2 \mathbf{l}, 21.83 \mathrm{~min}$ ] (see Supporting Information for HPLC chromatography).

\section{Marine fungal strains and culture conditions}

The marine fungal strain Penicillium citrinum GIM 3.458, Penicillium citrinum GIM 3.251, and Penicillium citrinum GIM 3.100 were isolated from the sponge Chelonaplysylla erecta, collected in Dapeng Bay, Shenzhen, China. Aspergillus sclerotiorum AS 3.2578, Aspergillus sydowii AS 3.7839, Aspergillus sydowii AS 3.6412 were isolated from the sponge Haliclona simulans, collected in Hainan Island, Hainan, China. Geotrichum candidum GIM 2.361, Geotrichum candidum GIM 2.616, Rhodotorula rubra GIM 2.31, and Rhodotorula mucilageinosa GIM 2.157 were isolated from the Chinese cnidarian zoanthids, i.e., Palythoa variabilis, Palythoa caribaeorum, and Mussismilia hispida, respectively, collected from Zhuhai City. Geotrichum candidum AS 2.1183, Geotrichum candidum AS 2.498, and Rhodotorula rubra AS 2.2241 were isolated from a marine alga Caulerpa sp., collected in Zhoushan Island, Zhejiang, China. All the strains used in this study were deposited and commercially available in Guangdong Culture Collection Center (strains with collection numbers starting from GIM were available from here: http://www.gimcc.net/prolist.asp) or the China General Microbiological Culture Collection Center (strains with collection numbers starting from AS were available from here: $\mathrm{http} / /$ www.cgmec.net/english/).

The marine fungi were maintained on agar plates at $4{ }^{\circ} \mathrm{C}$ and subcultured at regular intervals. The medium used for cultivation contained glucose $(15 \mathrm{~g} / \mathrm{L})$, peptone $(5 \mathrm{~g} / \mathrm{L})$, yeast extract (grease, $5 \mathrm{~g} / \mathrm{L})$, disodium hydrogen phosphate $(0.5 \mathrm{~g} /$ 
L), sodium dihydrogen phosphate $(0.5 \mathrm{~g} / \mathrm{L})$, magnesium sulfate $(0.5 \mathrm{~g} / \mathrm{L})$, and sodium chloride $(10 \mathrm{~g} / \mathrm{L})$ and a final $\mathrm{pH} 7.0$; this medium was sterilized at $115{ }^{\circ} \mathrm{C}$ in an autoclave for 25 min. A loopful of a single colony was cut from the agar stock cultures and used to inoculate $1 \mathrm{~L}$ medium in a $2-\mathrm{L}$ Erlenmeyer flask. This culture was shaken reciprocally at $28{ }^{\circ} \mathrm{C}$ for approximately $48-96 \mathrm{~h}$. The cells were harvested either by centrifugation at $4000 \mathrm{rpm}$ and at $4{ }^{\circ} \mathrm{C}$ for $20 \mathrm{~min}$ or filtered through filter bags. The supernatant was removed, and the cells were rinsed with a $\mathrm{Na}_{2} \mathrm{HPO}_{4}-\mathrm{KH}_{2} \mathrm{PO}_{4}$ buffer $(100 \mathrm{mM}, \mathrm{pH}$ 7.0) and centrifuged again. The supernatant was discarded and the pellets were stored at $-20{ }^{\circ} \mathrm{C}$.

\section{Chemical synthesis of the standard racemic $\beta$-phenylalcohols $2 a, 2 c, 2 d, 2 g-2 j$, and $2 \mathrm{l}$}

Ten millimoles of $\mathrm{NaBH}_{4}$ was added to a cooled $\left(0^{\circ} \mathrm{C}\right)$ solution of $2.5 \mathrm{mmol}$ of each specific substrate $(\mathbf{1 a}, \mathbf{1 c}, \mathbf{1 d}, \mathbf{1 g}-\mathbf{1 j}$, and 11) in $50 \mathrm{~mL}$ of methanol. After stirring for $10 \mathrm{~min}$, the mixture was warmed to room temperature and stirred for another 3-4 h to complete the reduction. After quenching with $2 \mathrm{M} \mathrm{HCl}$ to $\mathrm{pH} 7.0$, the mixture was extracted with EtOAc $(50 \mathrm{~mL} \times 3)$. The organic phases were washed with brine, dried over $\mathrm{Na}_{2} \mathrm{SO}_{4}$, filtered, and concentrated in vacuum. The residue was purified by flash chromatography on silica gel (eluent: EtOAc/PE 1:20) to give the racemic alcohol 2a, $\mathbf{2 c}, \mathbf{2 d}, \mathbf{2 g}-\mathbf{2 j}$, and $\mathbf{2 l}$ (see Supporting Information for NMR spectroscopic data).

\section{General biotransformation procedure}

\section{Analytical procedure}

Reactions were performed in 50-mL screw-capped glass vials to prevent evaporation of substrate/product. Shaking was performed in a heated ground-top shaker at the given temperatures $\left(20-50{ }^{\circ} \mathrm{C}\right)$ with $220 \mathrm{rpm}$. Approximately, $3 \mathrm{~g}$ resting cells of strains A-L (wet cells) were resuspended in $10 \mathrm{~mL}$ of buffer (100 mM, pH 3.5-9.0) containing $0.5 \mathrm{~g}$ (co-substrates) and $10 \mathrm{mM}$ of aromatic ketones $(\mathbf{1 a}-\mathbf{1 m})$. For the blank reaction, the setup was the same but without the addition of cells. Reactions were allowed to proceed at the given temperatures for given times. For workup, the cells were removed by centrifugation and $2 \mathrm{~mL}$ of the supernatant was saturated with $\mathrm{NaCl}$ followed by extraction with $2 \times 1 \mathrm{~mL}$ of HPLC eluent ( $n$-hexane $/ i-\mathrm{PrOH}=95 / 5, v / v$ ) by shaking for $5 \mathrm{~min}$. The combined organic layer was dried over $\mathrm{Na}_{2} \mathrm{SO}_{4}$ and measured by HPLC for yield and ee.

\section{Preparative procedure}

Three hundred grams of resting cells of strains A-L were resuspended in $1000 \mathrm{~mL}$ of buffer $(100 \mathrm{mM}$ with appropriate
$\mathrm{pH}$ values) with $50 \mathrm{~g}$ co-substrate and $10 \mathrm{mM}$ of aromatic ketones 1a-1m. The reaction mixture was incubated at given temperatures and shaken at $220 \mathrm{rpm}$ for given times. The cells were removed by centrifugation and the supernatant was saturated with $\mathrm{NaCl}$. The supernatant was extracted with EtOAc $(1000 \mathrm{~mL} \times 3)$. The organic phases were washed with brine, dried over $\mathrm{Na}_{2} \mathrm{SO}_{4}$, filtered, and concentrated in vacuo. The residue was purified by flash chromatography on silica gel (eluent: EtOAc/PE 1:20) to give the corresponding enantiomerically pure alcohols.

\section{Effect of reaction temperature on asymmetric reduction of propiophenone catalyzed by $R$. mucilageinosa GIM 2.157 cells}

Reactions were performed in 50-mL screw-capped glass vials to prevent evaporation of substrate/product. Shaking was performed in a heated ground-top shaker at the given temperatures with $220 \mathrm{rpm}$. Approximately $3 \mathrm{~g}$ resting cells of $R$. mucilageinosa GIM 2.157 (wet cells) were resuspended in $10 \mathrm{~mL}$ of $\mathrm{Na}_{2} \mathrm{HPO}_{4}-\mathrm{KH}_{2} \mathrm{PO}_{4}$ buffer (100 mM, pH 7.0) containing $0.5 \mathrm{~g}$ glucose and $10 \mathrm{mM}$ of propiophenone (1a). For the blank reaction, the setup was the same but without the addition of cells. Reactions were allowed to proceed at the given temperatures for $24 \mathrm{~h}$. For workup, the cells were removed by centrifugation and $2 \mathrm{~mL}$ of the supernatant was saturated with $\mathrm{NaCl}$ followed by extraction with $2 \times 1 \mathrm{~mL}$ of HPLC eluent ( $n$ hexane $/ i-\mathrm{PrOH}=95 / 5, v / v)$ by shaking for $5 \mathrm{~min}$. The combined organic layer was dried over $\mathrm{Na}_{2} \mathrm{SO}_{4}$ and measured by HPLC for yield and ee (Fig. 1a).

\section{Effect of reaction time on asymmetric reduction of propiophenone catalyzed by R. mucilageinosa GIM 2.157 cells}

The reaction setup for the time study was the same as for the temperature study. Reactions were performed in $\mathrm{Na}_{2} \mathrm{HPO}_{4}$ $\mathrm{KH}_{2} \mathrm{PO}_{4}$ buffer $(100 \mathrm{mM}, \mathrm{pH} 7.0)$ containing propiophenone (1a, $10 \mathrm{mM}$ ), resting cells (R. mucilageinosa GIM 2.157, $0.3 \mathrm{~g} / \mathrm{mL})$ and glucose $(0.05 \mathrm{~g} / \mathrm{mL})$. At regular intervals, a $2 \mathrm{~mL}$ sample was taken from the reaction mixture. Workup and analysis were as described above in the "Effect of reaction temperature on asymmetric reduction of propiophenone catalyzed by $R$. mucilageinosa GIM 2.157 cells" section (Fig. 1b).

\section{Effect of buffer pH on asymmetric reduction of propiophenone catalyzed by R. mucilageinosa GIM 2.157 cells}

The reaction setup for the $\mathrm{pH}$ profile was the same as for the temperature study. Reactions were performed in buffer $(10 \mathrm{~mL})$ containing $10 \mathrm{mM}$ of substrate $1 \mathbf{a}, 3 \mathrm{~g}$ of resting cells (R. mucilageinosa GIM 2.157), and glucose $(0.5 \mathrm{~g})$ at given 
$\mathrm{pH}$ values $(\mathrm{pH} 3.5-6.5$ were prepared as citrate/phosphate buffers and $\mathrm{pH} 7.0-9.0$ were prepared as disodium hydrogen phosphate/potassium dihydrogen phosphate at a buffer strength of $100 \mathrm{mM}$ ) at $25^{\circ} \mathrm{C}$ for $24 \mathrm{~h}$. Workup and analysis were as described above in "Effect of reaction temperature on asymmetric reduction of propiophenone catalyzed by R. mucilageinosa GIM 2.157 cells" (Fig. 1c).

\section{Effect of substrate concentration on asymmetric reduction of propiophenone catalyzed by $R$. mucilageinosa GIM 2.157 cells}

The reaction setup for the substrate concentration study was the same as for the temperature study. Reactions were performed in $10 \mathrm{~mL} \mathrm{Na}_{2} \mathrm{HPO}_{4}-\mathrm{KH}_{2} \mathrm{PO}_{4}$ buffer (100 mM, pH 7.0) containing $3 \mathrm{~g}$ of resting cells ( $R$. mucilageinosa GIM 2.157), glucose $(0.5 \mathrm{~g})$, and the given amount of propiophenone (1a, 3.33, $6.66,10,13.3,16.7,20 \mathrm{mM}$ ) at $25^{\circ} \mathrm{C}$ for $24 \mathrm{~h}$. Workup and analysis were as described above in the "Effect of reaction temperature on asymmetric reduction of propiophenone catalyzed by R. mucilageinosa GIM 2.157 cells" (Fig. 1d).

\section{General procedure for recyclability}

Reactions were performed with substrate $1 \mathbf{a}(10 \mathrm{mM})$ in $10 \mathrm{~mL}$ of $\mathrm{Na}_{2} \mathrm{HPO}_{4}-\mathrm{KH}_{2} \mathrm{PO}_{4}$ buffer $(100 \mathrm{mM}, \mathrm{pH} 7.0)$ and $3 \mathrm{~g}$ of wet cells of $R$. mucilageinosa GIM 2.157 (or $R$. rubra AS 2.2241), shaken at $25^{\circ} \mathrm{C}$ for $23 \mathrm{~h}$. At the end of the reaction, cells were centrifuged at $4000 \mathrm{rpm}$ for $20 \mathrm{~min}$ to separate them from the reaction mixture, washed by $\mathrm{Na}_{2} \mathrm{HPO}_{4}-\mathrm{KH}_{2} \mathrm{PO}_{4}$ buffer (100 mM, pH 7.0), and resuspended in $10 \mathrm{~mL}$ in the same buffer containing the same substrates. The reaction mixture $(2 \mathrm{~mL}$ of supernatant separated from cells) was saturated with $\mathrm{NaCl}$ and extracted with $1 \mathrm{~mL}(\times 2)$ of HPLC eluents $(n$-hexane $/ i$-PrOH $=$ $95 / 5, v / v)$ by shaking for $5 \mathrm{~min}$. The combined organic phases were dried over $\mathrm{Na}_{2} \mathrm{SO}_{4}$ and crude samples were analyzed by HPLC (results are given in Figs. 3 and 4).

\section{Commercial-scale synthesis of enantiomeric alcohols $2 \mathrm{a}-2 \mathrm{~d}, \mathbf{2 g}-\mathbf{2 j}$, and $2 \mathrm{l}$}

For isolation and characterization of the bioreduction product, the reaction was performed on a commercial scale: $300 \mathrm{~g}$ resting cells of $R$. mucilageinosa GIM 2.157 were resuspended in $1000 \mathrm{~mL}$ of $\mathrm{Na}_{2} \mathrm{HPO}_{4}-\mathrm{KH}_{2} \mathrm{PO}_{4}$ buffer $(100 \mathrm{mM}, \mathrm{pH} 7.0)$ with $50 \mathrm{~g}$ glucose and $10 \mathrm{mM}$ of each substrate $(\mathbf{1} \mathbf{a}-\mathbf{1 d}, \mathbf{1 g}-\mathbf{1 j}$, and $\mathbf{1 l})$. The reaction mixture was incubated at $25{ }^{\circ} \mathrm{C}$ and shaken at $220 \mathrm{rpm}$ for $24 \mathrm{~h}$. The cells were removed by centrifugation and the supernatant was saturated with $\mathrm{NaCl}$. The supernatant was extracted with EtOAc $(1000 \mathrm{~mL} \times 3)$. The organic phases were washed with brine, dried over $\mathrm{Na}_{2} \mathrm{SO}_{4}$, filtered and concentrated in vacuo. The residue was purified by flash chromatography on silica gel (eluent: EtOAc/PE 1:20) to give the enantiomerically pure alcohols $\mathbf{2 a}-\mathbf{2 d}, \mathbf{2 g}-\mathbf{2 j}$, and 21. The isolated yield (92-95\%) and ee of preparative scale are comparable to those obtained from screening biotransformations. The spectroscopic data $\left({ }^{1} \mathrm{H}\right.$ and ${ }^{13} \mathrm{C}$ NMR, and HPLC retention times) of enantiomeric alcohols $\mathbf{2 a - 2 d}, \mathbf{2 g}-$ $\mathbf{2 j}$, and $\mathbf{2} \mathbf{l}$ are in agreement with those obtained for racemic forms, as described above. The optical rotations of isolated enantiomeric alcohols $\mathbf{2 a}$ and $\mathbf{2 c}, \mathbf{2 d}, \mathbf{2 g}-\mathbf{2} \mathbf{j}$, and $\mathbf{2 l}$ are as follows: $(S)-\mathbf{2 a},[\alpha]_{\mathrm{D}}{ }^{20}-38.5$ (c 1.00 in $\left.\mathrm{MeOH}\right)$, lit[Gilmore et al. 2004] $[\alpha]_{\mathrm{D}}{ }^{20}-45.4\left(c 1.00\right.$ in $\left.\mathrm{CHCl}_{3}\right)$ for $(S)-\mathbf{2 a}$; $(R)-\mathbf{2 c},[\alpha]_{\mathrm{D}}{ }^{20}-16.9$ (c 0.35 in $\left.\mathrm{MeOH}\right)$, lit[Gilmore et al. 2004] $[\alpha]_{\mathrm{D}}{ }^{20}-30.9\left(c 1.00\right.$ in $\left.\mathrm{CHCl}_{3}\right)$ for $(R)-\mathbf{2 c} ;(S)-\mathbf{2 d},[\alpha]_{\mathrm{D}}{ }^{20}+9.68(c 0.05$ in $\mathrm{MeOH})$, lit[Gilmore et al. 2004] $[\alpha]_{\mathrm{D}}{ }^{20}-5.5\left(c 1.00\right.$ in $\left.\mathrm{CHCl}_{3}\right)$ for (R)-2d; $(S)-\mathbf{2 g},[\alpha]_{\mathrm{D}}{ }^{20}-17.3(c$ 0.1.00 in $\mathrm{MeOH}), \operatorname{lit}[\mathrm{Du}$ et al. 2006] $[\alpha]_{\mathrm{D}}{ }^{20}+16.0\left(c 1.70\right.$ in $\left.\mathrm{CH}_{2} \mathrm{Cl}_{2}\right)$ for $(R)-\mathbf{2 g}$; $(S)-\mathbf{2 h},[\alpha]_{\mathrm{D}}^{20}-66.49(c 1.00$ in $\mathrm{MeOH})$, lit[Inagaki et al. $2010][\alpha]_{\mathrm{D}}{ }^{20}+46.1\left(c 1.70\right.$ in $\left.\mathrm{CHCl}_{3}\right)$ for $(R)-\mathbf{2 h} ;(S)-\mathbf{2 i}$, $[\alpha]_{\mathrm{D}}{ }^{20}-49.7$ (c 1.00 in $\left.\mathrm{MeOH}\right)$, lit[Inagaki et al. 2010] $[\alpha]^{\mathrm{D}}+40.4\left(c \quad 1.00\right.$ in $\left.\mathrm{CHCl}_{3}\right)$ for $(R)-\mathbf{2} \mathbf{i} ;(S)-\mathbf{2} \mathbf{j},[\alpha]_{\mathrm{D}}{ }^{20}$ $78.4(c 1.00$ in $\mathrm{MeOH})$, lit[Matharu et al. 2005] $[\alpha]_{\mathrm{D}}{ }^{20}+$ $48.8\left(c 1.00\right.$ in $\left.\mathrm{CHCl}_{3}\right)$ for $(R)-\mathbf{2} \mathbf{j} ;(R)-\mathbf{2 l},[\alpha]_{\mathrm{D}}{ }^{20}-26.1(c$ 0.80 in $\mathrm{MeOH})$, lit[Olivares-Romero and Juaristi 2008] $[\alpha]_{\mathrm{D}}{ }^{20}+32.8\left(c 1.08\right.$ in $\left.\mathrm{CHCl}_{3}\right)$ for $(R)-\mathbf{2 l}$.

\section{Results}

\section{Optimization}

To fully assess the potential of marine-derived fungi as biocatalysts for the enantioselective reduction of aromatic ketones, we began our investigation with optimization of reaction conditions. After initial experiments (see Table S1 in the Supporting Information) of asymmetric reduction of ketones $\mathbf{1 a}-\mathbf{1} \mathbf{m}$ catalyzed by strains Penicillium citrinum GIM 3.458, Penicillium citrinum GIM 3.251, Penicillium citrinum GIM 3.100, Aspergillus sclerotiorum AS 3.2578, Aspergillus sydowii AS 3.7839, Aspergillus sydowii AS 3.6412, Geotrichum candidum GIM 2.361, Geotrichum candidum GIM 2.616, Rhodotorula rubra GIM 2.31, Rhodotorula mucilageinosa GIM 2.157, Rhodotorula rubra AS 2.2241, Geotrichum candidum AS 2.498, and Geotrichum candidum AS 2.1183, we found that seven strains of 13 could reduce ketones $\mathbf{1 a}-\mathbf{1 d}$ and $\mathbf{1 g}-\mathbf{1 j}$ into the corresponding enantiomeric alcohols smoothly. Although the conversions were not excellent due to the fact that all the reactions were performed without optimization, we chose propiophenone (1a) due to the fact that it is the cheapest substrate ( $1 \mathrm{~L} / 45$ euro) and the strain R. mucilageinosa GIM 2.157 due to the fact that only this strain could convert extra substrate $\mathbf{1 l}$ into the chiral 
Fig. 1 Temperature profile (a), time course (b), $\mathrm{pH}$ profile (c), and substrate concentration study (d) of the bioreduction of propiophenone (1a) using resting cells of the strain $R$. mucilageinosa GIM 2.157. For reaction conditions, see the "Materials and Methods" section. Yield and $e e$ values were determined by chiral HPLC. Filled circles represent yield of $(S)$-2a. Filled squares represent $e e$ of $(S)$ 2a
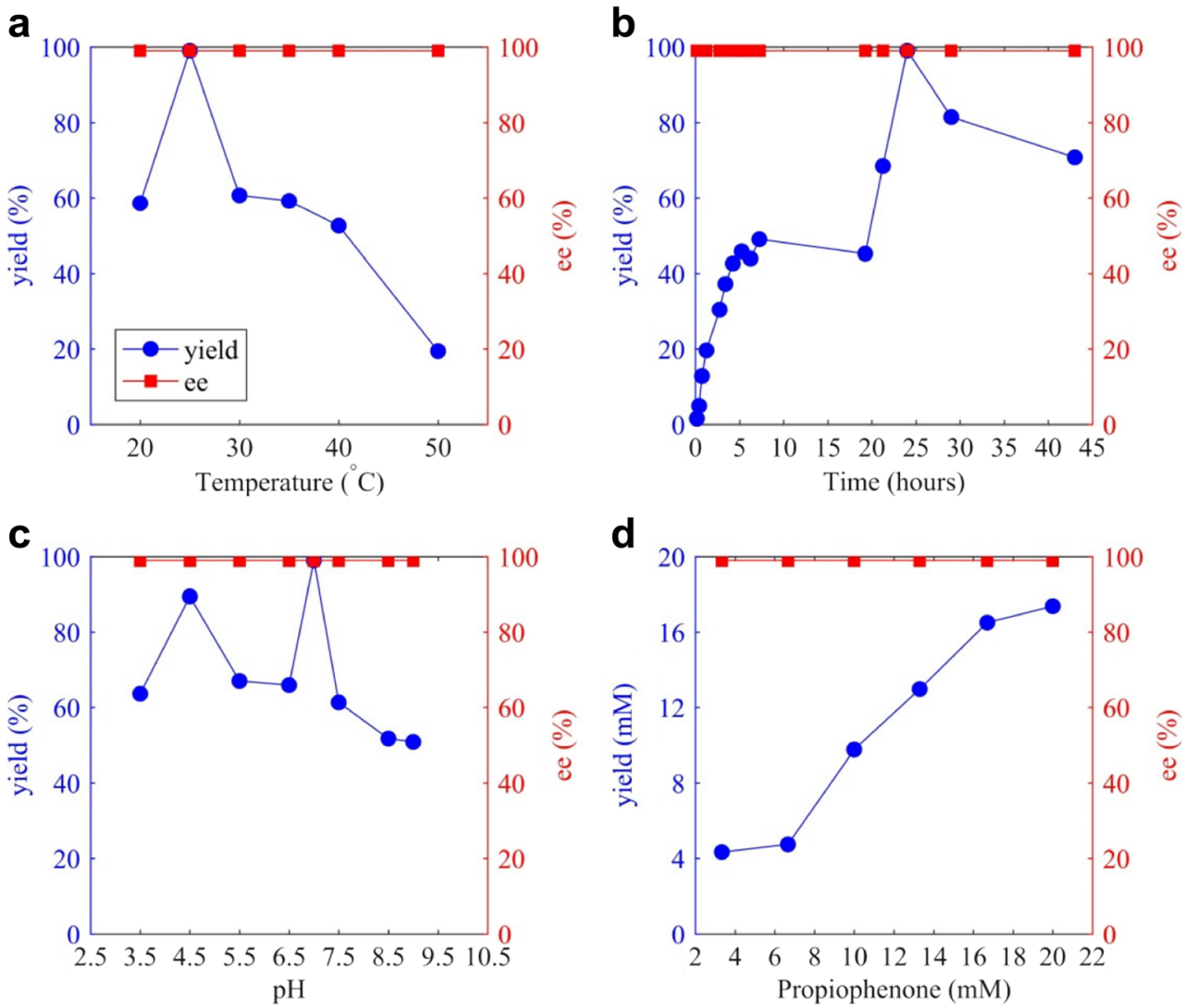

d

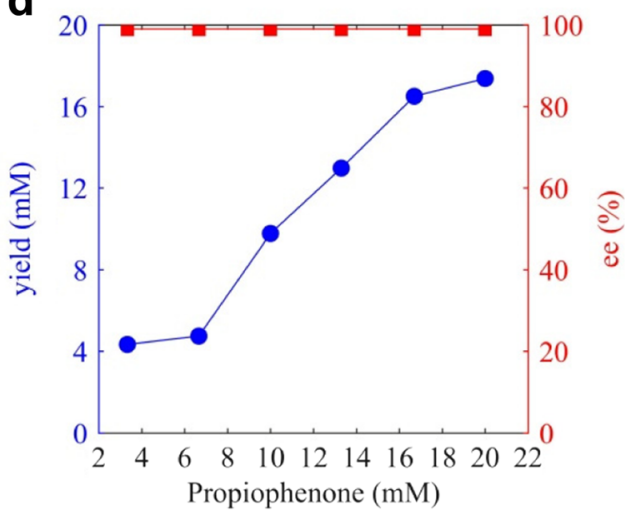

alcohol (see Table S1 in the Supporting Information) as the main tested substrate and strain (Scheme 1). The first reaction was performed with $10 \mathrm{~mL}$ of $\mathrm{Na}_{2} \mathrm{HPO}_{4}-\mathrm{KH}_{2} \mathrm{PO}_{4}$ buffer $(100 \mathrm{mM}, \mathrm{pH} 6.0)$ containing glucose $(0.5 \mathrm{~g}), 5 \mathrm{mM}$ of propiophenone (1a), and $3 \mathrm{~g}$ resting cells of Rhodotorula mucilageinosa GIM 2.157 at $30{ }^{\circ} \mathrm{C}$, due to its frequent use for biotransformation in our laboratory. Overnight $(17 \mathrm{~h})$, the desired product $(S)-1$ phenylpropan-1-ol [(S)-2a] was observed in 50\% yield and $99 \%$ ee after proper workup. In a control reaction containing only propiophenone (1a), glucose, and buffer (without resting cells) performed in parallel, no yield of the desired product $(S)$-1-phenylpropan-1-ol [(S)-2a] was detected, indicating that there was no chemically catalyzed reaction taking place; thus, the reaction was effected by the active enzymes present in the strain $R$. mucilageinosa GIM 2.157 .

Encouraged by the good results of the first experiment, a systematic investigation was made of the effects of several important variables to the reactions. Yields and $e e$ values of the desired product $(S)$-2a at various temperatures $\left(20-50{ }^{\circ} \mathrm{C}\right)$ are summarized in Fig. 1a. The product yield increased substantially from 20 to $25^{\circ} \mathrm{C}$, while the product ee showed no significant change and remained above $99 \%$. However, when the reaction temperature was increased above $25{ }^{\circ} \mathrm{C}$, a clear drop in product yield (and hence enzyme activity) was observed. At $50{ }^{\circ} \mathrm{C}$, a product yield of less than $20 \%$ was detected, although the ee was maintained above $99 \%$. This might be due to the side-reactions such as the intermolecular aldol reactions; in addition, dehydration of the desired product $(S)-1$ phenylpropan-1-ol [(S)-2a] can easily occur at higher temperatures. The partial inactivation of the cells at higher temperatures might also be a factor; Nakamura et al. (1991) suggested that the ketone reductase was not stable above $40{ }^{\circ} \mathrm{C}$. Taking both yield and enantioselectivity into account, the best result was achieved at $25{ }^{\circ} \mathrm{C}$, in agreement with the reported (Chandran and Das 2012) optimal growth temperature of $25-28{ }^{\circ} \mathrm{C}$ for $R$. mucilageinosa.

Because complete conversion was not obtained during the first experiment overnight, the bioreduction reaction rate was evaluated at $25{ }^{\circ} \mathrm{C}$ and revealed clear trend towards an increase in product formation over time during the first $24 \mathrm{~h}$ of<smiles>CCC(=O)c1ccccc1</smiles>

1 a<smiles>CC[C@H](O)c1ccccc1</smiles>

(S)-2a
Scheme 1 Bioreduction of propiophenone (1a) by strain $R$. mucilageinosa GIM 2.157 
the reaction, except for between $7.25 \mathrm{~h}$ and $19.25 \mathrm{~h}$, which showed no acceleration with time (Fig. 1b). This may be because the ketone reductases present in the strain $R$. mucilageinosa GIM 2.157 are light-dependent (Moliné et al. 2010) and the period between 7.25 and $19.25 \mathrm{~h}$ (overnight) is dark, limiting the activity of the enzymes. In a whole-cell reaction, (S)-1-phenylpropan-1-ol might be oxidized back into propiophenone if the alcohol dehydrogenases were also present. Chandran and Das (2012) have reported that genus Rhodotorula possess an array of alcohol dehydrogenases. This allows the explanation of the decrease of formation of (S)-1-phenylpropan-1-ol between 7.25 and $19.25 \mathrm{~h}$ depending on the activity of alcohol dehydrogenases. Another possibility was that if the (de)hydratases were also present in the whole fungus cell, catalyzing the reversible hydration-dehydration reaction (Boersma 2010; Bos 2013; Chen et al. 2015; Jin et al. 2011), there would exist an equilibrium between $(S)-1$ phenylpropan-1-ol and the eliminated product $(E)$-prop-1-en1-ylbenzene. The presence of (de)hydratases might be one of the reasons why the desired reduction product $(S)-1$ phenylpropan-1-ol decreased at particular times. So far, no (de)hydratases has been found in Rhodotorula strains. Further experiments regarding this hypothesis are currently being implemented in our laboratory. By sequencing and annotation of the genome of strain R. mucilageinosa GIM 2.157, it would be straightforward to see if strain $R$. mucilageinosa GIM 2.157 harbors alcohol dehydrogenases and (de)hydratases. Complete conversion of $\mathbf{1 a}$ [ $>99 \%$ yield of (S)-2a] was obtained after $24 \mathrm{~h}$, although the desired product formation decreased over 24 to $43 \mathrm{~h}$. This decrease might indicate the presence of alcohol dehydrogenase in the strain R. mucilageinosa GIM 2.157, as was also found by Chandran and Das (2012). This enzyme competed with ketone reductase after $24 \mathrm{~h}$, resulting in the degradation and hence the decrease in the desired product $(S)$-2a yield. No significant changes in product ee (almost above 99\%) within the study times were observed. Overall, reactions must be performed for $24 \mathrm{~h}$ to reach complete conversion.

The influence of varying reaction $\mathrm{pH}$ was also evaluated between 3.5 and 9.0 at $25^{\circ} \mathrm{C}$ for $24 \mathrm{~h}$. Potassium phosphate buffer ( $\mathrm{pH} 7.0-9.0)$ and citrate/phosphate buffer ( $\mathrm{pH} 3.5-6.5$ ) were used to control the $\mathrm{pH}$ of the reaction medium. As shown in Fig. 1c, product formation varied with $\mathrm{pH}$, as buffer $\mathrm{pH}$ values generally affect the activity and selectivity of cells, as well as the regeneration of the coenzyme present in microbial cells. Hence, buffer $\mathrm{pH}$ can alter the ionic state of the ketone reductases involved in the reaction and influence the local polarity of the active sites of ketone reductases. The optimal activity was observed at $\mathrm{pH} 4.5$ (desired product $(S)$-2a at $89.4 \%$ yield and $99 \% e e$ ) and $\mathrm{pH} 7.0$ (desired product $(S)$-2a at $99 \%$ yield and $99 \%$ ee), indicating that there might be two different ketone reductases (with optimal activity at different $\mathrm{pH}$ values) present in the strain $R$. mucilageinosa GIM 2.157.
Notably, there were no significant changes in the enantioselectivity of the desired (S)-2a (kept above 99\%) within the measured $\mathrm{pH}$ ranges. Taking into account the yield and product $e e, \mathrm{pH} 7.0$ was considered the optimal $\mathrm{pH}$ for the bioreduction.

We then studied the influence of substrate concentration on the outcome of the reduction reaction at $\mathrm{pH} 7.0$ and $25^{\circ} \mathrm{C}$ for $24 \mathrm{~h}$. Desired product formation and enantioselectivity are shown in Fig. 1d. This revealed an almost linear increase in product formation with increasing propiophenone (1a) concentrations ranging from 3.33 and $20 \mathrm{mM} ; 16.7 \mathrm{mM}$ was the maximum concentration of propiophenone (1a) in buffer with the help of the solubilizer DMSO $(0.5-1.0 \%)$. Remarkably, for substrate concentrations of 6.66-13.3 mM, product formation increased rapidly, suggesting $10 \mathrm{mM}$ is a good substrate concentration for this biotransformation. This concentration was used for all further studies. For all ranges of substrate concentrations tested, product ee did not change significantly and was maintained above $99 \%$.

One remaining challenge for the biocatalytic reduction reactions is its high dependence on expensive cofactors (such as $\mathrm{NADH} / \mathrm{NADPH}$ ), which forbids its stoichiometric use on a large scale. In principle, this can be overcome by using whole cells without adding expensive NADH/NADPH, but a co-substrate is required to recycle the coenzyme (Stewart 2000). Different cosubstrates varied largely in terms of product yield and ee when they were employed for the cofactor regeneration system of some bioreduction reactions in earlier studies (Quezada et al. 2009; Wolfson and Dlugy 2006). Therefore, several commonly used co-substrates, such as organic solvent (methanol, ethanol, and 2propanol), metabolites (glucose and fructose), and thermal stabilizer (sodium lactate) were screened to find the best co-substrate for the reduction of propiophenone (1a) using resting cells of the strain $R$. mucilageinosa GIM 2.157. As shown in Table 1, propiophenone (1a) could be reduced to (S)-1-phenylpropan-1ol $[(S)$-2a] without adding co-substrate (control), implying that the whole-cell system was capable of generating cofactor $\mathrm{NAD}(\mathrm{P}) \mathrm{H}$ for the reduction through cellular metabolism. However, each added co-substrate markedly influenced the product yields; in all cases, the product ee was above $99 \%$. It was obvious that methanol, ethanol, 2-propanol, glucose, sodium lactate, and fructose could effectively improve cellular metabolism to regenerate cofactor $\mathrm{NAD}(\mathrm{P}) \mathrm{H}$, leading to enhanced product formation. Glucose was the best co-substrate, with the highest production yield of $99 \%$.

\section{Substrate specificity and limitation}

We next turned our attention to the substrate scope and limitation of strain R. mucilageinosa GIM 2.157 for the reduction of aromatic ketones. Another 12 aromatic ketones that were structurally closely related to the main test substrate 1 a were tested (Fig. 2) under the optimized conditions, and the results 
Table 1 Effect of co-substrate on reduction of propiophenone (1a) by $R$. mucilageinosa GIM 2.157

\begin{tabular}{lllll}
\hline Co-substrate & Time (h) & Yield (\%) & ee (\%) & Config. \\
\hline No co-substrate & 24 & 56.7 & 99 & $\mathrm{~S}$ \\
Methanol & 24 & 78.4 & 99 & $\mathrm{~S}$ \\
Ethanol & 24 & 62.8 & 99 & $\mathrm{~S}$ \\
2-Propanol & 24 & 60.6 & 99 & $\mathrm{~S}$ \\
Glucose & 24 & 99 & 99 & $\mathrm{~S}$ \\
Sodium lactate & 24 & 86.6 & 99 & $\mathrm{~S}$ \\
Fructose & 24 & 64.8 & 99 & $\mathrm{~S}$ \\
\hline
\end{tabular}

are presented in Table 2. Since the corresponding racemic reduction product $( \pm)-\beta$-phenylalcohols $\mathbf{2 a}-\mathbf{2} \mathbf{m}$ (except $\mathbf{2 b}$ ) were not commercially available, they were obtained by reduction of the aromatic ketones $1 \mathbf{a}$ and $\mathbf{1 c}-\mathbf{1 m}$ with sodium borohydride in methanol (Pavia et al. 1999) and used as standard compounds for analysis of bioreduction products via chiral HPLC. The NMR spectra of synthesized standard racemic compounds $\mathbf{2 a}$ and $\mathbf{2 c - 2} \mathbf{m}$ are shown in the Supporting Information and are in agreement with those reported in the literature (Gilmore et al. 2004; Inagaki et al. 2010; Matharu et al. 2005; Olivares-Romero and Juaristi 2008).

When the tested substrates were aromatic ketones with no substituents in the benzene ring (1a-1d), the yield (more than 99\%) and the product $e e$ (more than 99\%) were very satisfactory, except for 3-chloro-1-phenylpropan-1-one (1e), likely due to its more bulky structure. $R$. mucilageinosa GIM 2.157 cells did not accept substrates with electron-donating groups in the para-position such as 1-(4-methoxyphenyl)ethanone (1f) and 1-(4-hydroxyphenyl)ethanone (1k). Interestingly, for aromatic ketones with an electron-attractive group in the benzene ring $(\mathbf{1 g}-\mathbf{1 j})$, the reaction proceeded smoothly in all cases to yield the corresponding reduction products with excellent yield
Table 2 Stereoselective reduction of various ketones with R. mucilageinosa GIM 2.157 cells

\begin{tabular}{lllll}
\hline Entry & Substrates & Yield (\%) & Ee (\%) & Config. \\
\hline 1 & 1a & 99 & 99 & $S$ \\
2 & $\mathbf{1 b}$ & 99 & 99 & $S$ \\
3 & $\mathbf{1 c}$ & 99 & 99 & $R$ \\
4 & $\mathbf{1 d}$ & 99 & 99 & $S$ \\
5 & $\mathbf{1 e}$ & n.c. & n.d. & n.d. \\
6 & $\mathbf{1 f}$ & n.c. & n.d. & n.d. \\
7 & $\mathbf{1 g}$ & 99 & 99 & $S$ \\
8 & $\mathbf{1 h}$ & 99 & 99 & $S$ \\
9 & $\mathbf{1 i}$ & 99 & 99 & $\mathrm{~S}$ \\
10 & $\mathbf{1 j}$ & 99 & 99 & $S$ \\
11 & $\mathbf{1 k}$ & n.c. & n.d. & n.d. \\
12 & $\mathbf{1 1}$ & 50 & 99 & $R$ \\
13 & $\mathbf{1 m}$ & n.c. & n.d. & n.d. \\
\hline
\end{tabular}

Reaction conditions: $10 \mathrm{~mL} \mathrm{Na} \mathrm{HPO}_{4}-\mathrm{KH}_{2} \mathrm{PO}_{4}$ buffer $(100 \mathrm{mM}, \mathrm{pH}$ 7.0), $3 \mathrm{~g}$ wet cells, $10 \mathrm{mM}$ various aromatic ketones, $0.5 \mathrm{~g}$ glucose, $25^{\circ} \mathrm{C}, 24 \mathrm{~h}$;

Yield and ee were determined by chiral HPLC analysis equipped with a Chiracel AD-H chiral column (see "Materials and Methods" section);

n.c. no conversion, $n . d$. not determined

(more than 99\%) and enantioselectivity (more than 99\%). Thus, we chose three aromatic ketones with chlorosubstituents at para-, meta- and ortho-positions, respectively, as model substrates $(\mathbf{1} \mathbf{h}-\mathbf{1 j})$ to elucidate the impact of the position of substituent groups on enzyme activity; the results showed that $R$. mucilageinosa GIM 2.157 was able to catalyze the reduction of all three tested substrates to the corresponding alcohols with excellent yields and enantioselectivities. When there electron-attractive groups at both the para-position of the benzene ring and side-chain of the carbonyl group, such
Fig. 2 Structurally related aromatic ketones used for bioreduction by marine-derived fungi as catalysts<smiles>CCC(=O)c1ccccc1</smiles>

$1 a$<smiles>CC(=O)c1ccccc1</smiles>

$1 \mathrm{~b}$<smiles>O=C(CBr)c1ccccc1</smiles>

1c<smiles>O=C(CCl)c1ccccc1</smiles>

$1 d$<smiles>O=C(CCCl)c1ccccc1</smiles>

$1 \mathrm{e}$<smiles>COc1ccc(C(C)=O)cc1</smiles>

$1 f$<smiles>CC(=O)c1ccc(Br)cc1</smiles>

$1 \mathrm{~g}$<smiles>CC(=O)c1ccc(Cl)cc1</smiles>

$1 \mathrm{~h}$<smiles>CC(=O)c1cccc(Cl)c1</smiles>

$1 \mathrm{i}$<smiles>CC(=O)c1ccccc1Cl</smiles>

1j<smiles>CC(=O)c1ccc(O)cc1</smiles><smiles>O=C(CBr)c1ccc(Br)cc1</smiles><smiles>O=C(CBr)c1ccc([N+](=O)[O-])cc1</smiles> 
as in substrate $\mathbf{1 1}$, the corresponding reduction product was obtained with $50 \%$ yield and $99 \%$ ee. However, for a substrate with an electron-attractive group in the side-chain of the carbonyl group and electron-donating group in the para-position of the benzene ring, such as substrate $\mathbf{1 m}$, no reduction product was detected, implying that substrates with electron-donating groups in the para-position of the benzene ring inhibited the enzyme activity of $R$. mucilageinosa GIM 2.157, similar to substrates $\mathbf{1 f}$ and 1k. As shown in Fig. 2 and Table 2, all the tested 13 substrates could be reduced by $R$. mucilageinosa GIM 2.157 cells into the corresponding enantiomeric alcohols with good yield and excellent $e e$, apart from 1e, 1f, 1k, and 1m. A closer look at the structures of $\mathbf{1 b}, \mathbf{1 g}, \mathbf{1 h}, \mathbf{1} \mathbf{i}, \mathbf{1} \mathbf{j}$ vs $\mathbf{1 f}$, and $\mathbf{1 k}$ (as shown in Fig. 3) revealed that substrates with electron-donating group in the para-position were not accepted by R. mucilageinosa GIM 2.157 cells. Thus we assumed that substrates with electron-donating groups in the para-position of the benzene ring inhibited the enzyme activity of $R$. mucilageinosa GIM 2.157. Enzyme stereoselectivity depends on the orientation of bound substrate, which is under the control of interactions between the substrate and the residues in the substrate binding site, such as hydrophobic/van der Waals forces, electrostatic interactions or hydrogen bonding (Zhu and Hua 2010). Remarkably, among the nine substrates accepted by $R$. mucilageinosa GIM 2.157, seven were reduced to the corresponding $(S)$-alcohols following Prelog's rule, while two were reduced to the corresponding $(R)$-alcohols following the antiPrelog's rule. To the best of our knowledge, most ketone reductases follow Prelog's rule and usually afford the $(S)$-alcohols (Prelog 1964), while only a few whole-cell biocatalysts have been reported to be anti-Prelog $(R)$-specific (Tujigami et al.
2001; Gröger et al. 2006; Hu and Xu 2006; Lavandera et al. 2008; Xiao et al. 2009; Brautigam et al. 2009). The varied enantioselectivity of strain $R$. mucilageinosa GIM 2.157 might be due to the presence of different ketone reductases in the cells; such details would be significant for potential industrial applications.

\section{Distribution of ketone reductases in various marine fungi}

To establish the distribution of enzymatic activity, we proceeded with testing various marine-derived fungi. Penicillium citrinum GIM 3.458, Penicillium citrinum GIM 3.251, Penicillium citrinum GIM 3.100, Aspergillus sclerotiorum AS 3.2578, Aspergillus sydowii AS 3.7839, Aspergillus sydowii AS 3.6412, Geotrichum candidum GIM 2.361, Geotrichum candidum GIM 2.616, Geotrichum candidum AS 2.1183, Geotrichum candidum AS 2.498, Rhodotorula rubra AS 2.2241, and Rhodotorula rubra GIM 2.31 were comparatively tested for their potential for bioreduction of aromatic ketones (1a-1d and $\mathbf{1 g}-\mathbf{1 j}$ ) under conditions optimized for Rhodotorula mucilageinosa GIM 2.157. The results are presented in Table 3. Two other Rhodotorula strains, Rhodotorula rubra AS 2.2241 (strain A) and Rhodotorula rubra GIM 2.31 (strain B), were also capable of catalyzing the stereoselective reduction of the tested eight aromatic ketones to the corresponding alcohols, showing the same and excellent activity and enantioselectivity compared to the strain Rhodotorula mucilageinosa GIM 2.157. These results suggest that promising ketone reductase activity is not limited to Rhodotorula mucilageinosa GIM
Fig. 3 Structure comparison of accepted substrates $\mathbf{1 b}, \mathbf{1 h}, \mathbf{1 g}$, and $\mathbf{1 i}$ and unaccepted substrates $1 \mathbf{f}$ and $\mathbf{1 k}$

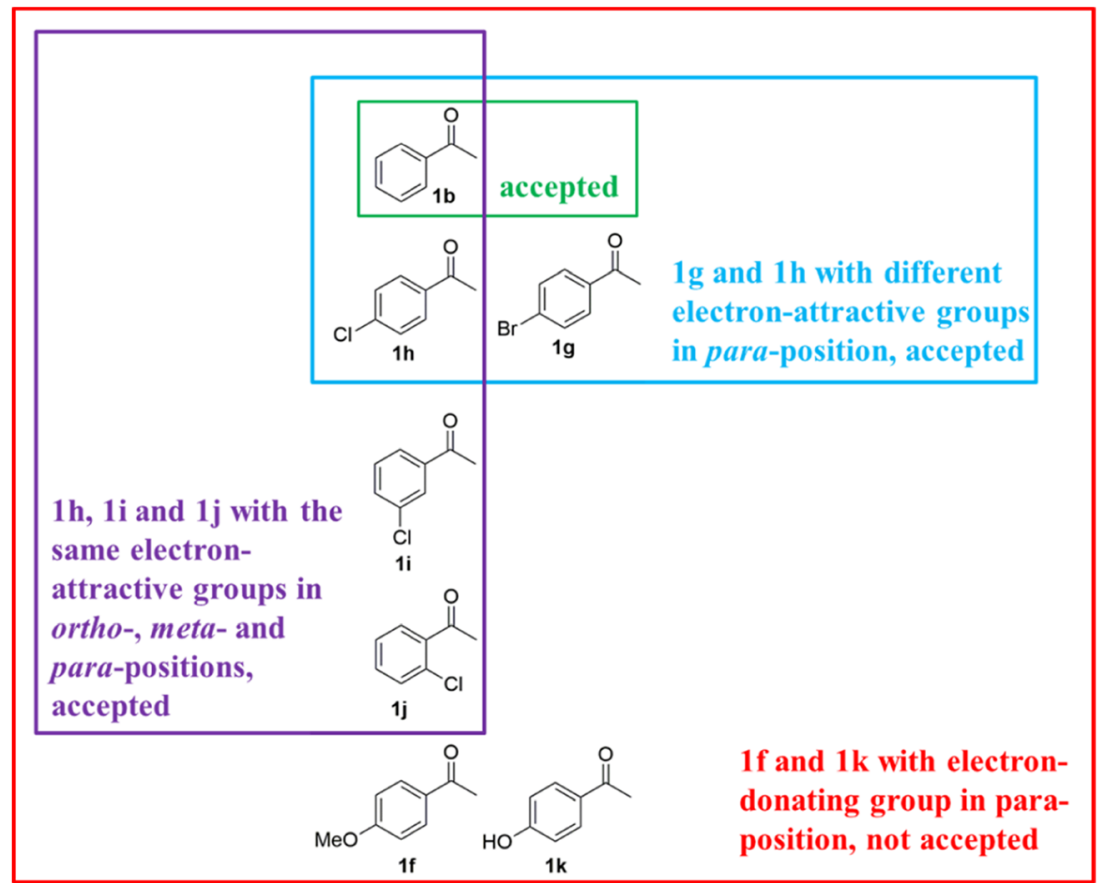


Table 3 Screening marine fungal strains for aromatic ketone reductase activity

\begin{tabular}{|c|c|c|c|c|c|c|}
\hline \multirow[t]{2}{*}{ Substrate } & \multicolumn{6}{|c|}{ Marine fungal strains } \\
\hline & $\mathrm{A}$ & B & $\mathrm{C}$ & $\mathrm{D}$ & E & $\mathrm{F}$ \\
\hline $1 \mathrm{a}$ & $99\left(\mathrm{ee}_{S}=99\right)$ & $99\left(\mathrm{ee}_{S}=99\right)$ & $52\left(\mathrm{ee}_{S}=81\right)$ & $43\left(\mathrm{ee}_{S}=97\right)$ & $58\left(\mathrm{ee}_{S}=91\right)$ & $33\left(\mathrm{ee}_{S}=89\right)$ \\
\hline $1 b$ & $99\left(\mathrm{ee}_{S}=99\right)$ & $99\left(\mathrm{ee}_{S}=99\right)$ & $63\left(\mathrm{ee}_{S}=87\right)$ & $56\left(\mathrm{ee}_{S}=89\right)$ & $35\left(\mathrm{ee}_{S}=87\right)$ & $41\left(\mathrm{ee}_{S}=86\right)$ \\
\hline $1 \mathrm{c}$ & $99\left(\mathrm{ee}_{R}=99\right)$ & $99\left(\mathrm{ee}_{R}=99\right)$ & $41\left(\mathrm{ee}_{R}=87\right)$ & $85\left(\mathrm{ee}_{R}=81\right)$ & $29\left(\mathrm{ee}_{R}=59\right)$ & $99\left(\mathrm{ee}_{R}=98\right)$ \\
\hline $1 d$ & $99\left(\mathrm{ee}_{S}=99\right)$ & $99\left(\mathrm{ee}_{S}=99\right)$ & $24\left(\mathrm{ee}_{S}=18\right)$ & $18\left(\mathrm{ee}_{S}=2\right)$ & $32\left(\mathrm{ee}_{S}=31\right)$ & $10\left(\mathrm{ee}_{S}=42\right)$ \\
\hline $1 \mathrm{~g}$ & $99\left(\mathrm{ee}_{S}=99\right)$ & $99\left(\mathrm{ee}_{S}=99\right)$ & $49\left(\mathrm{ee}_{S}=75\right)$ & $45\left(\mathrm{ee}_{S}=60\right)$ & $24\left(\mathrm{ee}_{S}=22\right)$ & $34\left(\mathrm{ee}_{S}=17\right)$ \\
\hline $1 \mathrm{~h}$ & $99\left(\mathrm{ee}_{S}=99\right)$ & $99\left(\mathrm{ee}_{S}=99\right)$ & $54\left(\mathrm{ee}_{S}=59\right)$ & $98\left(\mathrm{ee}_{S}=26\right)$ & $68\left(\mathrm{ee}_{S}=50\right)$ & $54\left(\mathrm{ee}_{S}=63\right)$ \\
\hline $1 \mathrm{i}$ & $99\left(\mathrm{ee}_{S}=99\right)$ & $99\left(\mathrm{ee}_{S}=99\right)$ & $96\left(\mathrm{ee}_{S}=99\right)$ & $97\left(\mathrm{ee}_{S}=99\right)$ & $53\left(\mathrm{ee}_{S}=99\right)$ & $81\left(\mathrm{ee}_{S}=99\right)$ \\
\hline $1 \mathrm{j}$ & $99\left(\mathrm{ee}_{S}=99\right)$ & $99\left(\mathrm{ee}_{S}=99\right)$ & $81\left(\mathrm{ee}_{S}=90\right)$ & $83\left(\mathrm{ee}_{S}=99\right)$ & $59\left(\mathrm{ee}_{S}=92\right)$ & $80\left(\mathrm{ee}_{S}=92\right)$ \\
\hline
\end{tabular}

Strains G-L showed no activity for bioreduction of tested substrates; results not shown.

Reaction conditions: $10 \mathrm{~mL} \mathrm{Na} 2 \mathrm{HPO}_{4}-\mathrm{KH}_{2} \mathrm{PO}_{4}$ buffer $(100 \mathrm{mM}, \mathrm{pH} 7.0), 3 \mathrm{~g}$ wet cells, $10 \mathrm{mM}$ substrate, $0.5 \mathrm{~g}$ glucose, $25^{\circ} \mathrm{C}, 24 \mathrm{~h}$

$52\left(\mathrm{ee}_{S}=81\right)$ indicates $52 \%$ yield of the desired $(S)$-selective reduction product with $81 \%$ enantioselectivity for all the data listed in the table above

Yield and ee were determined by chiral HPLC analysis equipped with a Chiracel AD-H chiral column (see the "Materials and Methods" section)

Configuration was assigned by comparing the specific signs of rotation measured for the isolated products with those reported in the literature (see the "Substrate specificity and limitation" section)

$A, R$. rubra AS 2.2241; B, R. rubra GIM 2.31; C, G. candidum GIM 2.361; D, G. candidum GIM 2.616; $E$, G. candidum AS 2.1183; F, G. candidum AS 2.498; G, P. citrinum GIM 3.458; H, P. citrinum GIM 3.251; I, P. citrinum GIM 3.100; J, A. sclerotiorum AS 3.2578; $K$, A. sydowii AS 3.7839; L, A. sydowii AS 3.6412
2.157 but may be a general feature in several Rhodotorula strains. Encouraged by these results, several less related Geotrichum strains, including G. candidum GIM 2.361 (strain C), G. candidum GIM 2.616 (strain D), G. candidum AS 2.1183 (strain E), and G. candidum AS 2.498 (strain F) were also tested for ketone reductase activity. Gratifyingly, all four Geotrichum strains exhibited catalytic activity, although they were slightly less active than Rhodotorula strains in terms of yield and product $e e$ for the bioreduction of eight tested aromatic ketones (1a-1d and $\mathbf{1} \mathbf{g}-\mathbf{1 j})$ examined under the same reaction conditions. The varied activities of these Geotrichum strains might be attributable to the differential expression of (different) reductases in cells, but this topic requires further investigation. When Penicillium strains, including Penicillium citrinum GIM 3.458 (strain G), Penicillium citrinum GIM 3.251 (strain H), Penicillium citrinum GIM 3.100 (strain I), and Aspergillus strains including Aspergillus sclerotiorum AS 3.2578 (strain J), Aspergillus sydowii AS 3.7839 (strain K), Aspergillus sydowii AS 3.6412 (strain L), were tested for ketone reductase activity using eight aromatic ketones (1a-1d and $\mathbf{1 g}-\mathbf{1 j}$ ) as testing substrates, no desired reduction products were obtained. This result is surprising, as the Porto group (Rocha et al. 2010, 2012, 2015; de Oliveira et al. 2014; De Vitis et al. 2015) reported that Aspergillus sclerotiorum CBMAI 849 and Penicillium citrinum CBMA 1186 (Brazilian marine filamentous fungus) catalyzed the biotransformation of $\alpha$-bromoacetophenones to the corresponding alcohols with good yields and enantioselectivities. Comparison of the results obtained with the tested Chinese Penicillium and Aspergillus strains to those reported for Brazilian strains suggests that strains from different sources have different expression of (different) enzymes, such as ketone reductases. This is supported by the findings of van den Brink and de Vries (2011), who concluded that the variety of the enzyme set often differs between fungi and corresponds to the requirements of the habitat. Indeed, marine fungi must adapt to specific conditions in different marine ecosystems, and therefore produce different extracellular enzymes and secondary metabolites from different sources. Rhodotorula strains exhibited the greatest, most obvious potential for efficient asymmetric reduction of aromatic ketones to enantiomerically pure chiral alcohols among the examined 13 marine fungal strains.

\section{Reusability of cells}

To ensure the practical application of a catalyst, its operational stability and reusability over an extended period of time should be considered as one of the most important characteristics (Schrewe et al. 2013). From a process economics point of view, the more cycles that an enzyme remains active, the more efficiently a process can be run. Therefore, experiments were performed to examine the recyclability of the whole cells of selected strains of Rhodotorula mucilageinosa GIM 2.157 and Rhodotorula rubra AS 2.2241 for the reduction of propiophenone (1a) as an example. In the results summarized in Fig. 1, every reaction was performed in $10 \mathrm{~mL} \mathrm{Na}_{2} \mathrm{HPO}_{4^{-}}$ 


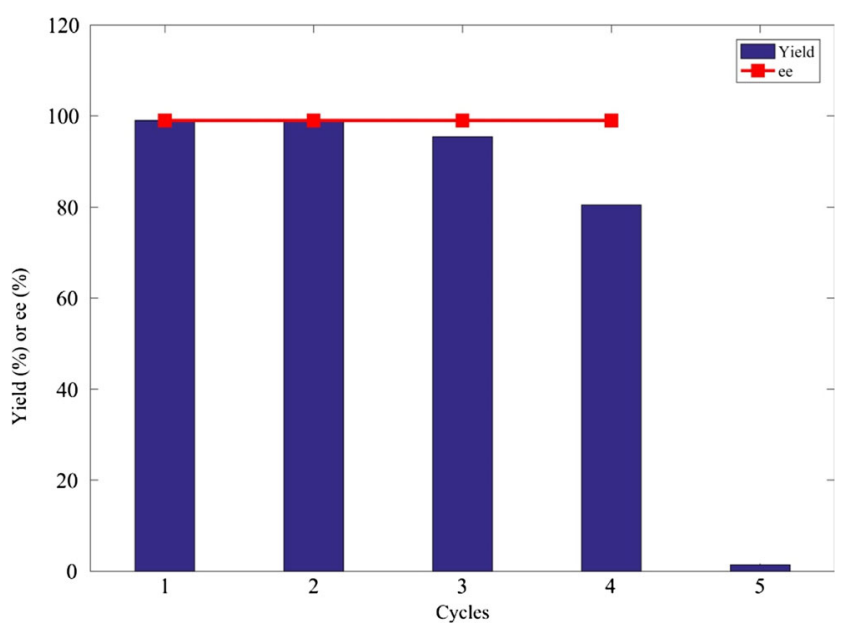

Fig. 4 Repeated bioreduction of propiophenone (1a) catalyzed by whole cells of Rhodotorula mucilageinosa GIM 2.157. Yield and product ee values were determined by chiral HPLC

$\mathrm{KH}_{2} \mathrm{PO}_{4}$ buffer (100 mM, pH 7.0) with $3 \mathrm{~g}$ wet cells, $10 \mathrm{mM}$ substrate and $0.5 \mathrm{~g}$ glucose and shaken at $25^{\circ} \mathrm{C}$ for $23 \mathrm{~h}$. At the end of the reaction, the cells were centrifuged, washed twice with the same buffer $\left[\mathrm{Na}_{2} \mathrm{HPO}_{4}-\mathrm{KH}_{2} \mathrm{PO}_{4}\right.$ buffer (100 mM, pH 7.0)] and reused for the next cycle under the same reaction conditions. Rhodotorula mucilageinosa GIM 2.157 cells showed high activity and complete conversion for two cycles. Only a slight decrease was observed from cycle 3 , whereas almost no activity (1.4\% yield of desired product) was retained in cycle 5 (Fig. 4). Notably, no significant changes in the enantioselectivities of the reduction using propiophenone (1a) as the tested substrate were detected during the four cycles. Rhodotorula rubra AS 2.2241 cells were far superior to Rhodotorula mucilageinosa GIM 2.157 in terms of operational stability and reusability over an extended period of time. Whole cells of strain Rhodotorula rubra AS 2.2241 exhibited high activity and complete conversion for nine cycles (Fig. 5). Only a slight decrease was observed in cycle 10 , whereas almost no activity $(2.6 \%$ yield of the desired product) was maintained in cycle 11 . Remarkably, the reduction product ee showed no significant variation and remained above $99 \%$.

\section{Discussion}

We have assigned the $(S)$-configuration to $\mathbf{2 a}, \mathbf{2 b}, \mathbf{2} \mathbf{d}$, and $\mathbf{2} \mathbf{g}$ $2 \mathbf{j}$ by comparison of the optical rotation with those obtained in previous reports for these enantiomeric alcohols. The $(S)$ configuration agrees to Prelog's rule, which predict that hydrogen transfer to the prochiral ketones occurs to the face where the large group is in the right side (Scheme 2), in this case the re faces.

Prelog's rule can often be used to predict the stereoselectivity of ketoreductases, by looking at the size of the two groups. This rule states that the enzyme has a large and small pocket that makes up the active site in which the substrate binds and controls the stereochemistry of the product based on the geometry of the substrate. The $R$. mucilageinosa GIM 2.157 enzyme seems to follow the Prelog's rule. When a ketone substrate binds, its larger L-group is bound in the small pocket and the smaller S-group in the larger pocket. Then the hydride source of the cofactor attacks from the above resulting in an alcohol that has pushed out, corresponding to Prelog rule behavior (Cundari et al. 2007).
Fig. 5 Repeated bioreduction of propiophenone (1a) catalyzed by whole cells of Rhodotorula rubra AS 2.2241. Yield and product ee values were determined by chiral HPLC

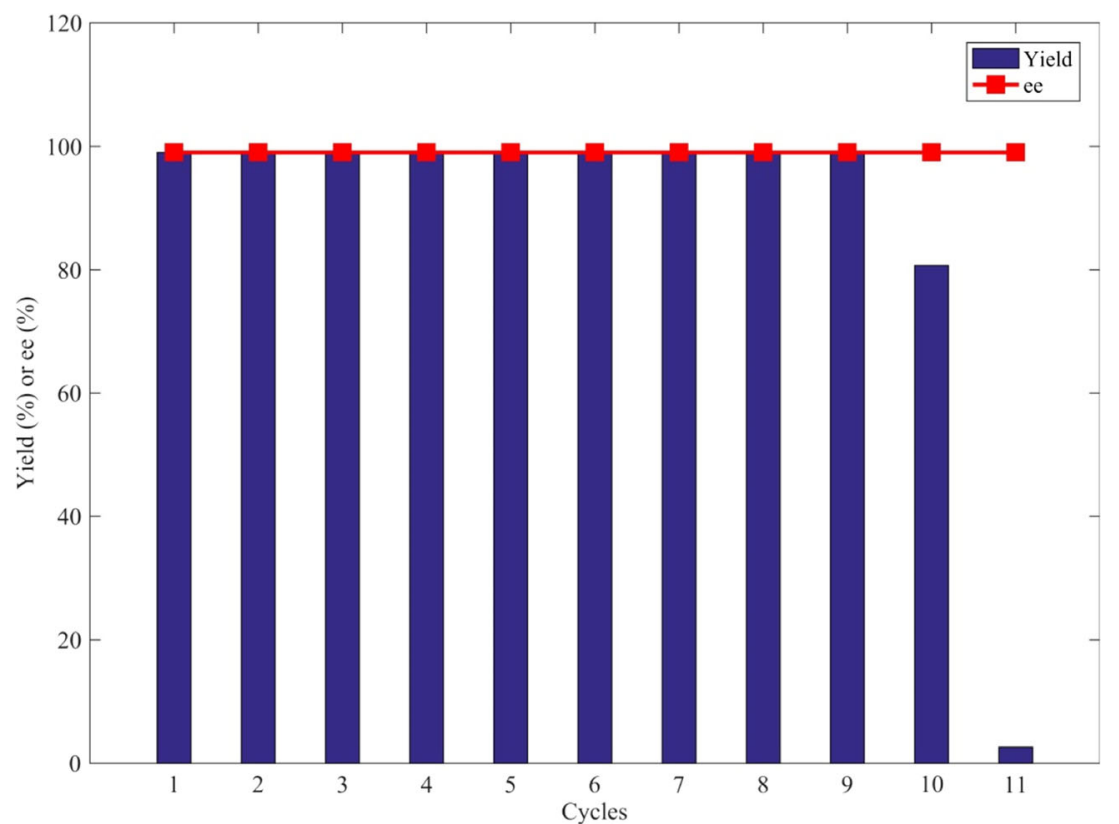




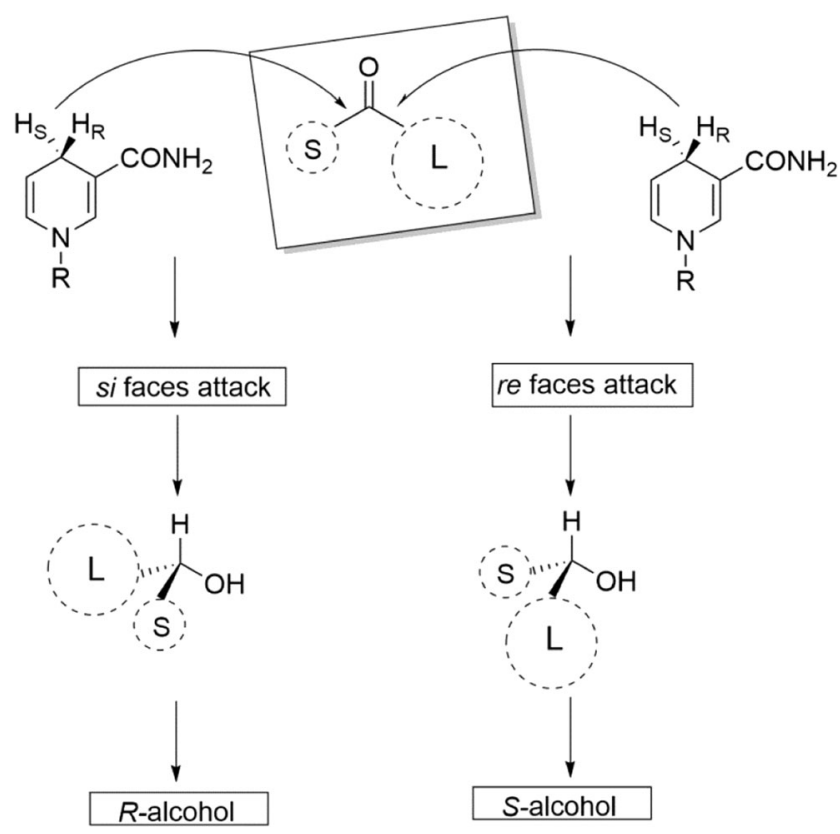

Scheme 2 Mechanism of stereoselectivity for $R$. mucilageinosa GIM 2.157 catalyzing reduction of ketones. Group priorities are based on Cahn-Ingold-Prelog rules and assume in the scheme to be $\mathrm{OH}>\mathrm{L}>\mathrm{S}$

However, the Prelog's rule has been reported to be highly substrate dependent, as shown in this study that between 1c and $\mathbf{1 d}$ the stereochemistry reversed. This is supported by the findings of Nguyen and co-workers (Nguyen et al. 2014), who found that a carbonyl reductases from red yeast Sporobolomyces salmonicolor displayed the anti-Prelog rule
21 out of 26 times for the ketones. In particular, they observed a reversal in the stereochemistry as the $n$-alkyl group length increases, such as propiophenone had anti-Prelog rule stereoselectivity while 1-phenylbutan-1-one showed Prelog behavior; 1- $p$-Tolylethanone had anti-Prelog rule stereoselectivity while 1-(4-(trifluoromethyl)phenyl)ethanone showed Prelog behavior (Table 4).

Optically pure chiral alcohols represent an important class of compounds that is often found as a structural motif in fine chemistry and the pharmaceutical sector. Catalytic enantioselective reduction of prochiral ketones is a highly demanding approach. Many metal-catalyzed methods have been developed. For example, the most well-known chemical reaction is that introduced by Noyori et al. (1987), who exploits the Noyori asymmetric hydrogenation of ketones using chiral ruthenium catalysts for the enantioselective hydrogenation of ketones, aldehydes, and imines. It needs to be emphasized that Ryoji Noyori shared half of the Nobel Prize in Chemistry in 2001 with William S. Knowles for the study of the asymmetric hydrogenation. In more details, BINAP-Ru catalyst is used for the asymmetric hydrogenation of functionalized ketones (Mashima et al. 1994) and BINAP/diamine-Ru catalyst is used for the asymmetric hydrogenation of simple ketones (Noyori and Ohkuma 2001). These hydrogenations are used in the production of several drugs, such as the antibacterial levofloxin, the antibiotic carbapenem, and the antipsychotic agent BMS181100 (Noyori 2002). Also, the hydrogenolysis of $\beta$-epoxy ketones using, such as, Bu3SnH/Bu3SnI/phosphine oxide or [Cp2TiCl] has been reported (Hardouin et al.
Table 4 Comparison of R. mucilageinosa GIM 2.157 cells with other ketoreductases regarding stereoselecitvity with Prelog's rule

\begin{tabular}{lllll}
\hline Compound & Ee $(\%)$ & Prelog & Strain & Reference \\
\hline Acetophenone & $42(R)$ & Anti & S. salmonicolor & Nguyen et al. 2014 \\
Propiophenone & $28(R)$ & Anti & S. salmonicolor & Nguyen et al. 2014 \\
1-Phenylbutan-1-one & $88(S)$ & Prelog & S. salmonicolor & Nguyen et al. 2014 \\
1-Phenylpentan-1-one & $87(S)$ & Prelog & S. salmonicolor & Nguyen et al. 2014 \\
1-p-Tolylethanone & $59(R)$ & Anti & S. salmonicolor & Nguyen et al. 2014 \\
1-(4-Methoxyphenyl)ethanone & $57(R)$ & Anti & S. salmonicolor & Nguyen et al. 2014 \\
1-(4-(Trifluoromethyl)phenyl)ethanone & $17(S)$ & Prelog & S. salmonicolor & Nguyen et al. 2014 \\
Heptan-2-one & $30(S)$ & Prelog & S. salmonicolor & Zhu et al. 2006 \\
Octan-2-one & $44(S)$ & Prelog & S. salmonicolor & Zhu et al. 2006 \\
Octane-3-one & $72(R)$ & Anti & S. salmonicolor & Zhu et al. 2006 \\
Ethyl 4-chloro-3-oxobutanoate & $97(S)$ & Prelog & S. cerevisiae & Zhu et al. 2007 \\
Ethyl 3-oxopentanoate & $61(R)$ & Anti & S. cerevisiae & Zhu et al. 2007 \\
Ethyl 4-methyl-3-oxopentanoate & $99(S)$ & Prelog & S. cerevisiae & Zhu et al. 2007 \\
2c & $99(R)$ & Anti & R. mucilageinosa & This study \\
2d & $99(S)$ & Prelog & R. mucilageinosa & This study \\
2g & $99(S)$ & Prelog & R. mucilageinosa & This study \\
2h & $99(S)$ & Prelog & R. mucilageinosa & This study \\
2l & $99(R)$ & Anti & R. mucilageinosa & This study \\
\hline
\end{tabular}


2001; Kawakami et al. 1995). Asymmetric aldol reactions rather than reduction of prochiral carbonyl compounds using Corey-Bakshi-Shibata (CBS) catalyst derived from proline has also been described (Corey et al. 1987). This approach requires cumbersome catalyst preparation due to the fact that the CBS catalyst has to be prepared from diphenylprolinol. Diphenylprolinol is condensed with a phenylboronic acid, or with borane, to give the CBS catalyst, which complexes in situ with borane to give the active catalyst (Lohray and Bhushan 1992). Another route involves the pyridinium-assisted ringopening of epoxide rings followed by $\mathrm{NaBH} 4$ reduction (AlAbed et al. 1996). Surprisingly, although intramolecular aldolization of keto aldehydes is rarely employed, good results have been obtained by using triazabicyclo[4.4.0]dec-5-ene (TBD) as base (Ghobril et al. 2008). However, a straightforward metal-free catalytic enantioselective reduction of prochiral carbonyl compounds remains challenging.

The biocatalytic preparation of optically pure chiral alcohols is a valid alternative to conventional chemical methods. Whole-cell based biocatalytic reduction has attracted great attention due to the unique advantages such as mild reaction conditions, environmental friendliness, regeneration of cofactors in situ, easy production and relatively low price; this method has therefore attracted great attention and been extensively investigated in recent years (Rodrigues et al. 2004s; Schmid et al. 2001; Wohlgemuth et al. 2010). To date, there is a number of works on enzymatic reduction of prochiral carbonyl compounds to produce chiral alcohols involving biocatalysts of terrestrial origin (Ni et al. 2013; Rocha et al. 2012), but little using marine organisms or their purified enzymes (Rocha et al. 2015; Trincone 2010; Veberlen et al. 2006). As far as we know, most of the previously reported terrestrial microorganisms have not been used for industrial preparation of chiral alcohols for their relatively low catalytic activity and stereoselectivity. For industrial application, the discovery of more efficient microorganisms would be of great significance. Enzymes produced by marine fungi often show higher stability under operational conditions. Thus, we investigated the use of marine-derived fungi (seven strains) for asymmetric bioreduction of aromatic ketones $(\mathbf{1 a}-\mathbf{1 d}, \mathbf{1 g}-$ 1j), affording the corresponding optically pure chiral alcohols in good yields and enantiomeric excesses. The reaction proceeds under mild conditions using whole cells of strains A-F, which are very easy and cheap to cultivate. Under the optimized conditions, we scaled up the biotransformation to a $1000-\mathrm{mL}$ scale to determine the scalability of the biocatalytic asymmetric reduction of substrates $\mathbf{1 a}-\mathbf{1 d}, \mathbf{1 g}-\mathbf{1 j}$, and $\mathbf{2 l}$ with R. mucilageinosa GIM 2.157. All reactions were allowed to proceed for $24 \mathrm{~h}$ until no more substrate was converted to the product as monitored by chiral HPLC. The products were extracted from the reaction mixture with ethyl acetate and isolated in a pure form after simple silica gel chromatography. Final chemical yields of more than $92 \%$ was achieved and the product $e e$ was maintained above $99 \%$. The absolute configurations of the reduction products $(S)-\mathbf{2 a},(S)-\mathbf{2} \mathbf{b},(R)-\mathbf{2} \mathbf{c},(S)$ 2d, $(S)-\mathbf{2 g},(S)-\mathbf{2 h},(S)-\mathbf{2} \mathbf{i},(S)-\mathbf{2} \mathbf{j}$, and $(R)-\mathbf{2 l}$ obtained by enzymatic reduction were determined by comparing the specific signs of rotation measured for the isolated products to those reported in the literature (Gilmore et al. 2004; Inagaki et al. 2010; Matharu et al. 2005; Olivares-Romero and Juaristi 2008), except for $(S)-\mathbf{2 b}$, for which the absolute configuration was determined by co-injection of commercially available (R)-2b onto chiral HPLC.

Although wild-type whole cells were used, good results were obtained, showing the potential of marine-derived enzymes in biocatalysis. This opens up an entirely new and minimally polluting approach to the synthesis of optically pure chiral alcohols on the laboratory and commercial scales for the use of marine-derived fungi for ketone reduction.

Acknowledgements This study was funded by the Basic Research Program of Sun Yat-Sen University (Grant Nos. 17lgpy58 and 17lgzd12), Natural Science Foundation of Guangdong Province (Grant Nos. 4200018823950 and 42000-18823952), the National Natural Science Foundation of China (Grant Nos. 21272289,41606167, 41706148, and 51709287), China's Marine Commonweal Research Project (Grant No. 201305017), and the special financial fund of innovative development of marine economic demonstration project (Grant No. GD2012-D01-001).

\section{Compliance with ethical standards}

Conflict of interest The authors declare that they have no conflict of interest.

Ethical approval This article does not contain any studies with human participants or animals performed by any of the authors.

\section{References}

Al-Abed Y, Naz N, Khan M, Voelter W (1996) Pyridinium ions adjacent to oxirane rings: useful intermediates for the stereospecific synthesis of $\beta$-hydroxy ketone. Angew Chem Int Ed 35(5):523-524. https:// doi.org/10.1002/anie.199605231

Antranikian G, Vorgias CE, Bertoldo C (2005) Extreme environments as a resource for fungi and novel biocatalysts. Adv Biochem Eng Biotech 96:219-262

Boersma AJ, Coquière D, Geerdink D, Rosati F, Feringa BL, Roelfes G (2010) Catalytic enantioselective syn hydration of enones in water using a DNA-based catalyst. N Chem 2(11):991-995. https://doi. org/10.1038/nchem.819

Bos J, García-Herraiz A, Roelfes G (2013) An enantioselective artificial metallo-hydratase. Chem Sci 4:3538-3582

Brautigam S, Dennewald D, Schurmann M, Lutje-Spelberg J, Pitner WR, Weuster-Botz D (2009) Whole-cell biocatalysis: evaluation of new hydrophobic ionic liquids for efficient asymmetric reduction of prochiral ketones. Enzym Microb Technol 45(4):310-316. https:// doi.org/10.1016/j.enzmictec.2009.06.015

Brenelli ECS, Fernandes JLN (2003) Stereoselective acylations of 1,2azidoalcohols with vinyl acetate, catalyzed by lipase Amano OS. Tetrahedron Asymmetry 14(10):1255-1259. https://doi.org/10. 1016/S0957-4166(03)00206-4 
Burton SG, Cowan DA, Woodley JM (2002) The search for the ideal biocatalyst. Nat Biotechnol 20(1):37-45. https://doi.org/10.1038/ nbt0102-37

Chandran P, Das N (2012) Role of plasmid in diesel oil degradation by yeast species isolated from petroleum hydrocarbon-contaminated soil. Environ Technol 33(6):645-652. https://doi.org/10.1080/ 09593330.2011.587024

Chen B-S, Yang L-H, Ye J-L, Huang T, Ruan Y-P, Fu J, Huang P-Q (2011) Diastereoselective synthesis and bioactivity of long-chain anti-2-amino-3-alkanols. Eur J Med Chem 46(11):5480-5486. https://doi.org/10.1016/j.ejmech.2011.09.010

Chen B-S, Hanefeld U (2013) Enantioselective preparation of $(R)$ - and (S)3-hydroxycyclopentanone by kinetic resolution. J Mol Catal B Enzym 85-86:239-242. https://doi.org/10.1016/j.molcatb.2012.09.015

Chen B-S, Resch V, Otten LG, Hanefeld U (2015) Enantioselective Michael addition of water. Chem Eur J 21(7):3020-3030. https:// doi.org/10.1002/chem.201405579

Chen B-S, Liu H, de Souza FZR, Liu L (2017) Organic solvent-tolerant marine fungi as catalysts for kinetic resolution of cyclic $\beta$-hydroxy ketones. Mar Biotechnol 19(4):351-361. https://doi.org/10.1007/ s10126-017-9755-7

Corey EJ, Bakshi RK, Shibata S (1987) Highly enantioselective borane reduction of ketones catalyzed by chiral oxazaborolidines: mechanism and synthetic implications. J Am Chem Soc 109(18):55515553. https://doi.org/10.1021/ja00252a056

Cundari TR, Dinescu A, Zhu D, Hua L (2007) A molecular modeling study on the enantioselectivity of aryl alkyl ketone reductions by a NADPH-dependent carbonyl reductase. J Mol Model 13(6-7):685690. https://doi.org/10.1007/s00894-007-0168-9

De Oliveira JR, Seleghim MHR, Porto ALM (2014) Biotransformation of methylphenylacetonitriles by Brazilian marine fungal strain Aspergillus sydowii CBMAI 934: eco-friendly reactions. Mar Biotechnol 16(2): 156-160. https://doi.org/10.1007/s10126-013-9534-Z

De Vitis V, Guidi B, Contente ML, Granato T, Conti P, Molinari F, Crotti E, Mapelli F, Borin S, Daffonchio D, Romano D (2015) Marine fungi as source of stereoselective esterases and ketoreductases: kinetic resolution of a prostaglandin intermediate. Mar Biotechnol 17(2):144-152. https://doi.org/10.1007/s10126-014-9602-Z

Dionisi HM, Lozada M, Olivera NL (2012) Bioprospection of marine fungi: biotechnological applications and methods. Rev Argent Microbiol 44:46-90

Du D-M, Fang T, Xu J, Zhang S-W (2006) Structurally well-defined, recoverable $C_{3}$-symmetric tris( $\beta$-hydroxy phosphoramide)-catalyzed enantioselective borane reduction of ketones. Org Lett 8: $1327-1330$

Ferrer M, Golyshina OV, Beloqui A, Golyshin PN (2012) Mining enzymes from extreme environments. Curr Opin Microbiol 10:207-214

Gavrilescua M, Chisti Y (2005) Biotechnology — a sustainable alternative for chemical industry. Biotechnol Adv 23(7-8):471-499. https://doi. org/10.1016/j.biotechadv.2005.03.004

Gilmore NJ, Jones S, Muldowney MP (2004) Synthetic applicability and in situ recycling of a $B$-methoxy oxazaborolidine catalyst derived from cis-1-amino-indan-2-ol. Org Lett 6(16):2805-2808. https://doi. org/10.1021/o1048916o

Ghobril C, Sabot C, Mioskowski C, Baati R (2008) TBD-catalyzed direct 5- and 6-enolexo aldolization of ketoaldehydes. Eur J Org Chem 2008(24):4104-4108. https://doi.org/10.1002/ejoc.200800539

Gröger H, Rollmann C, Chamouleau F, Sebastien I, May O, Wienand W, Drauz K (2006) Enantioselective reduction of 4-fluoroacetophenone at high substrate concentration using a tailor-made recombinant whole-cell catalyst. Adv Synth Catal 349:709-712

Hans-Peter M, Werbitzky O (2011) How green can the industry become with biotechnology. In: Junhua AT, Kazlauskas R (eds) Biocatalysis for green chemistry and chemical process development. Wiley, Hoboken
Hardouin C, Chevallier F, Rousseau B, Doris E (2001) Cp 2 TiCl-mediated selective reduction of $\alpha, \beta$-epoxy ketones. J Org Chem 66(3):10461048. https://doi.org/10.1021/jo001358g

Hertweck C (2009) The biosynthetic logic of polyketide diversity. Angew Chem Int Ed 48(26):4688-4716. https://doi.org/10.1002/anie. 200806121

$\mathrm{Hu}$ J, Xu Y (2006) Anti-Prelog reduction of prochiral carbonyl compounds by Oenococcus oeni in a biphasic system. Biotechnol Lett 28(14):1115-1119. https://doi.org/10.1007/s10529-006-9062-2

Inagaki T, Phong LT, Furuta A, Ito J, Nishiyama H (2010) Iron- and cobalt-catalyzed asymmetric hydrosilylation of ketones and enones with bis(oxazolinylphenyl)amine ligands. Chem Eur J 16(10):3090 3096. https://doi.org/10.1002/chem.200903118

Jin J, Straathof AJJ, Pinkse MWH, Hanefeld U (2011) Purification, characterization, and cloning of a bifunctional molybdoenzyme with hydratase and alcohol dehydrogenase activity. Appl Microbiol Biotechnol 89(6): 1831-1840. https://doi.org/10.1007/s00253-010-2996-2

Kawakami T, Tanizawa D, Shibata I, Baba A (1995) Chemo- and regioselective reductions of functionalized epoxides by $\mathrm{Bu}_{3} \mathrm{SnH} / \mathrm{Bu}_{3} \mathrm{SnI}-$ phosphine oxide. Tetrahedron Lett 36(51):9357-9360. https://doi. org/10.1016/0040-4039(95)02027-M

Lavandera I, Holler B, Kern A, Ellmer U, Glieder A, de Wildeman S, Kroutil W (2008) Asymmetric anti-Prelog reduction of ketones catalysed by Paracoccus pantotrophus and Comamonas sp. cells via hydrogen transfer. Tetrahedron Asymmetry 19(16):1954-1958. https://doi.org/10.1016/j.tetasy.2008.08.005

Liu Z, Weis R, Gliede A (2004) Enzymes from higher eukaryotes for industrial biocatalysis. Food Technol Biotechnol 42:237-249

Lohray BB, Bhushan V (1992) Oxazaborolidines and dioxaborolidines in enantioselective catalysis. Angew Chem Int Ed 31(6):729-730. https://doi.org/10.1002/anie.199207291

Mashima K, Kusano K, Sato N, Matsumura Y, Nozaki K, Kumobayashi H, Sayo N, Hori Y, Ishizaki T (1994) Cationic BINAP-Ru(II) halide complexes: highly efficient catalysts for stereoselective asymmetric hydrogenation of $\alpha$ - and $\beta$-functionalized ketones. J Org Chem 59(11):3064-3076. https://doi.org/10.1021/jo00090a026

Matharu DS, Morris DJ, Kawamoto AM, Clarkson G, Wills M (2005) A stereochemically well-defined rhodium(III) catalyst for asymmetric transfer hydrogenation of ketones. Org Lett 7(24):5489-5491. https://doi.org/10.1021/o1052559f

Moliné M, Flores MR, Libkind D, Diéguez MC, Farías ME, van Broock M (2010) Photoprotection by carotenoid pigments in the yeast Rhodotorula mucilaginosa: the role of torularhodin. Photochem Photobiol Sci 9(8):1145-1151. https://doi.org/10.1039/c0pp00009d

Nakamura K, Kawai Y, Nakajima N, Ohno A (1991) Stereochemical control of microbial reduction. 17. A method for controlling the enantioselectivity of reductions with bakers' yeast. J Org Chem 56(15):4778-4783. https://doi.org/10.1021/jo00015a038

Nguyen P-H, West M, Feske BD, Padgett CW (2014) Enantioselectivity and enzyme-substrate docking studies of a ketoreductase from Sporobolomyces salmonicolor (SSCR) and Saccharomyces cerevisiae (YOL151w). Int Sch Res Not ID 124289

Ni Y, Su Y, Li H, Zhou J, Sun Z (2013) Scalable biocatalytic synthesis of optically pure ethyl $(R)$-2-hydroxy-4-phenylbutyrate using a recombinant $E$. coli with high catalyst yield. J Biotechnol 168: 493-498.

Noyori R, Ohkuma T, Kitamura M, Takaya H, Sayo N, Kumobayashi H, Akutagawa S (1987) Asymmetric hydrogenation of beta-keto carboxylic esters. A practical, purely chemical access to beta-hydroxy esters in high enantiomeric purity. J Am Chem Soc 109(19):58565858. https://doi.org/10.1021/ja00253a051

Noyori R, Ohkuma T (2001) Asymmetric catalysis by architectural and functional molecular engineering: practical chemo- and stereoselective hydrogenation of ketones. Angew Chem Int Ed 40(1):40-43. https://doi.org/10.1002/1521-3773(20010105)40: $1<40:: A I D-A N I E 40>3.0 . C O ; 2-5$ 
Noyori R (2002) Asymmetric catalysis: science and opportunities (Nobel Lecture). Angew Chem Int Ed 41(12):2008-2022. https://doi.org/ 10.1002/1521-3773(20020617)41:12<2008::AID-ANIE2008>3.0. $\mathrm{CO} ; 2-4$

Olivares-Romero JL, Juaristi E (2008) Synthesis of three novel chiral diamines derived from $(S)$-proline and their evaluation as precursors of diazaborolidines for the catalytic borane-mediated enantioselective reduction of prochiral ketones. Tetrahedron 64(42):9992-9998. https://doi.org/10.1016/j.tet.2008.07.080

Pàmies O, Bäckvall J-E (2001) Syntheses and transformations of $\alpha$ azidoketones and related derivatives. J Org Chem 66(11):40224025. https://doi.org/10.1021/jo015579d

Patel RN (2008) Synthesis of chiral pharmaceutical intermediates by biocatalysis. Coordin Chem Rev 252(5-7):659-701. https://doi. org/10.1016/j.ccr.2007.10.031

Pavia DL, Lampman GM, Kriz GS, Engel RG (1999) Introduction to organic laboratory techniques, 3rd edn. Sunders College Publishing, Orlando

Prelog V (1964) Specification of the stereospecificity of some oxidoreductases by diamond lattice sections. Pure Appl Chem 9:119-130

Quezada MA, Carballeira JD, Sinisterra JV (2009) Monascus kaoliang CBS 302.78 immobilized in polyurethane foam using iso-propanol as co-substrate: optimized immobilization conditions of a fungus as biocatalyst for the reduction of ketones. Bioresour Technol 100(6): 2018-2025. https://doi.org/10.1016/j.biortech.2008.07.068

Rocha LC, Ferreira HV, Pimenta EF, Berlinck RGS, Rezende MOO, Landgraf MD, Seleghim MHR, Sette LD, Porto ALM (2010) Biotransformation of $\alpha$-bromoacetophenones by the marine fungus Aspergillus sydowii. Mar Biotechnol 12(5):552-557. https://doi.org/ 10.1007/s10126-009-9241-y

Rocha LC, Ferreira HV, Luiz RF, Sette LD, Porto ALM (2012) Stereoselective bioreduction of 1-(4-methoxyphenyl)ethanone by whole cells of marine-derived fungi. Mar Biotechnol 14(3):358362. https://doi.org/10.1007/s10126-011-9419-y

Rocha LC, Seleghim MHR, Comasseto JV, Sette LD, Porto ALM (2015) Stereoselective bioreduction of $\alpha$-azido ketones by whole cells of marine-derived fungi. Mar Biotechnol 17(6):736-742. https://doi. org/10.1007/s10126-015-9644-x

Rodrigues JAR, Moran PJS, Fardelone LC (2004) Recent advances in the Biocatalytic asymmetric reduction of acetophenones and $\alpha, \beta$ unsaturated carbonyl compounds. Food Technol Biotechnol 42: 295-303.

Sarkar S, Pramanik A, Mitra A, Mukherjee J (2010) Bioprocessing data for the production of marine enzymes. Mar Drugs 8(4):1323-1372. https://doi.org/10.3390/md8041323
Schmid A, Dordick JS, Hauer B, Kiener A, Wubbolts M, Witholt B (2001) Industrial biocatalysis today and tomorrow. Nature 409(6817):258-268. https://doi.org/10.1038/35051736

Schrewe M, Julsing MK, Bühler B, Schmid A (2013) Whole-cell biocatalysis for selective and productive $\mathrm{C}-\mathrm{O}$ functional group introduction and modification. Chem Soc Rev 42(15):6346-6377. https:/ doi.org/10.1039/c3cs60011d

Straathof AJJ (2013) Transformation of biomass into commodity chemicals using enzymes or cells. Chem Rev 114:1871-1908

Stewart JD (2000) Organic transformations catalyzed by engineered yeast cells and related systems. Curr Opin Biotechnol 11(4):363-368. https://doi.org/10.1016/S0958-1669(00)00111-7

Torrelo G, Hanefeld U, Hollmann F (2015) Biocatalysis. Catt Lett 145(1): 309-345. https://doi.org/10.1007/s10562-014-1450-y

Trincone A (2010) Potential biocatalysts originating from sea environments. J Mol Catal B Enzym 66(3-4):241-256. https://doi.org/10. 1016/j.molcatb.2010.06.004

Trincone A (2011) Marine biocatalysts: enzymatic features and applications. Mar Drugs 9(12):478-499. https://doi.org/10.3390/ md9040478

Tujigami T, Sugai T, Ohta H (2001) Microbial asymmetric reduction of $\alpha$-hydroxyketones in the anti-Prelog selectivity. Tetrahedron Asymmetry 12(18):2543-2549. https://doi.org/10.1016/S09574166(01)00448-7

Van den Brink J, de Vries RP (2011) Fungal enzyme sets for plant polysaccharide degradation. Appl Microbiol Biotechnol 91(6):14771492. https://doi.org/10.1007/s00253-011-3473-2

Verbelen PJ, De Schutter DP, Delvaux F, Verstrepen KJ, Delvaux FR, (2006) Immobilized yeast cell systems for continuous fermentation applications. Biotechnol Lett 28: 1515-1525.

Wolfson A, Dlugy C (2006) Baker's yeast catalyzed asymmetric reduction in glycerol. Tetrahedron Asymmetry 17(14):2043-2045. https:// doi.org/10.1016/j.tetasy.2006.07.026

Wohlgemuth R (2010). Biocatalysis - key to sustainable industrial chemistry. Curr Opin Cell Biol 21: 713-724.

Xiao ZJ, Zong MH, Lou WY (2009) Highly enantioselective reduction of 4-(trimethylsilyl)-3-butyn-2-one to enantiopure $(R)$-4(trimethylsilyl)-3-butyn-2-ol using a novel strain Acetobacter sp. CCTCC M209061. Bioresour Technol 100(23):5560-5565. https://doi.org/10.1016/j.biortech.2009.06.006

Zhu D, Yang Y, Buynak JD, Hua L (2006) Stereoselective ketone reduction by a carbonyl reductase from Sporobolomyces salmonicolor. Substrate specificity, enantioselectivity and enzyme-substrate docking studies. Org Biomol Chem 4(14):2690-2695. https://doi. org/10.1039/b606001c

Zhu D, Hua L (2010) How carbonyl reductases control stereoselectivity: approaching the goal of rational design. Pure Appl Chem 82:117-128 